\title{
Földes Györgyi
}

MTA BTK Irodalomtudományi Intézet

\section{A nyelv mint ellenség}

\section{Agota Kristof szövegei}

Agota Kristof Trilógiája - különösen, mióta az elsó részból készült film Szász János rendezésében komoly nemzetközi sikereket aratott

(Karlovy Vary Kristály Glóbusz-díj, Oscar-dij döntó) - rendkivül népszerú mú Franciaországban is, mint ahogy az irónó más szövegei (regények, novellák, drámák) úgyszintén. A Trilógiában éppúgy, mint Agota Kristof számos más szövegében (Az analfabéta, Tegnap, s több

novella) az emigráns/bevándorló alakja, a Másiknak ez a reprezentációja gyakran elófordul. Sajátságos narratív szövegeljárások miatt, melyekre a legérdekesebb példák éppen a

Trilógiában fordulnak eló (amely szövegben sokrétú játékot fedezhetünk fel a cselekmény elemeivel, a szereplókkel mint testi létezókkel, továbbá a nevekkel, személyes névmásokkal és bizonyos narrációs eljárásokkal), ezt a narratív életmúvet úgy is tekinthetjük, mint amelynek legfontosabb tétjei láthatóvá tenni az emigrációs identitás komplexitását, a határátlépés motívumát felhasználva rámutatni a vele járó transzgressziókra, és érthetóvé tenni azt a sajátos nyelvvesztést, amely mindamellett nyelvi nyereségként is értékelhetố. Az utóbbi lépés megtételéhez az ezzel a

veszteséggel-nyereséggel születố új nyelvet a Másik nyelvének kell tekintenünk, amelyet Deleuze és Guattari nyomán nomádnak, Homi K. Bhabha kifejezésével élve hibridnek, Donna Haraway manifesztuma után pedig kiborgnak is nevezhetünk.

A gota Kristof 1956-ban, 21 évesen hagyta el Magyarországot férjével és karonülő gyermekével. Minthogy nem tudott franciául, Neufchâtel-ben munkásnőként helyezkedett el egy óragyárban. Autodidakta módon tanult franciául, szótárakkal, és stílusgyakorlatokkal fejlesztette írástudását: így kezdődik irodalmi pályafutása, elöbb drámai mủvekkel, s csak később prózával (noha a gimnáziumban már írt verseket). Így lesz belőle magyar származású, franciául író magyar szerző, vagy másképp Svájcban letelepedett magyar bevándorló, aki franciául ír: helyzete mindenképpen felemás.

Ez a tapasztalat - sehová nem tartozni, két világ között lebegni - néha direkt módon is megjelenik a szövegeiben: „Hazamegyek az otthonomba, ami nekem nem volt soha, vagy ha igen, túl régen volt ahhoz, hogy emlékezzek rá, márpedig akkor soha nem volt az igazi otthonom." (Kristof, 2007, 12. o.) (az otthon címü novella). Vagy a Trilógiában: 
„Úgy megyek el, hogy senkit és semmit nem hagyok magam mögött. [...] Befut a vonat, felszállok. Csak egy böröndöm van. Semmivel sem viszek többet el innen, mint amennyivel érkeztem. Ebben a gazdag és szabad országban én nem szereztem vagyont. Turistavízumom van a szülőhazámba, csak egy hónapra érvényes, de meghosszabbítható." (Kristof, 2003, 359. o.)

Vagy A csatorna címü novellában bemutatott lázálomban, mikor is a föszereplő visszatér szülővárosába, és a tüz pusztította utcákon elveszetten bolyong, nyomában egy pumával, s nem találja a régi házukat, amelyben fiát hagyta. A bevándorló alakja a Másiké, a kisebbségiekhez tartozó külföldié, s mint ilyennek, el kell viselnie a többségi társadalom dominanciájának terhét, ugyanakkor átmeneti helyzetben is van, a halott zónában, a senki földjén.

Nem véletlen, hogy a Trilógia nagymamája - aki maga is bevándorló és ténylegesen analfabéta - ugyancsak határvidéken lakik unokáival, s életének egy bizonyos szakaszában Lucas T. is. Itt élve, s föként innen elindulva lehet a leginkább átlépni a határt földrajzi értelemben (mint ahogy az ikerpár egyik tagja teszi), de ugyanígy morális és/vagy testi értelemben is, átlépni a tiltások emelte korlátokon.

Melyek a ma is érvényes alapvető tiltások? A pedofília és az incesztus, márpedig ezekben a szövegekben ilyesféle bünöknek többször is tanúi lehetünk. Az ikrek tapasztalatai is értelmezhetők így éppen, de az áthágás, a transzgresszió (és vele együtt minden oppozicionális rendszer szubverziója) még erősebb Nyúlszáj esetében, aki egy kutyával közösül, vagy a homoszexuális és pedofil német tisztnél, akinek a gyerekeknek a fejére kell vizelniük, vagy éppen az ebben a zónában kibontakozó vérfertőző szerelmeket illetően: Yasmine és apja kapcsolata fizikai értelemben is itt zajlik, de Klaus incesztuózus szerelmének féltestvére, Sarah iránt - legalábbis metaforikusan - ugyancsak a határvidéken található végső oka. A vérfertőzés témája - amely a legevidensebb minden transzgresszió közül - amúgy Kristof életmüvében számos esetben megjelenik, lásd például Sandor gyöngéd érzelmeit (Caro)line iránt a Tegnapban, vagy a Line növérem, Lanoé fivérem címü novellát. (Egyébként Lévi-Strauss [1949] szerint a vérfertőzés tilalma a par excellence tiltás: kivételes és paradox, mivel egyszerre kulturális és univerzális, ami más esetekben kizárt: Lévi-Strauss ugyanis úgy gondolja, az embernél az univerzális általában a természet rendjéből ered és a spontaneitás jellemzi; és amit norma szabályoz, az a kultúra része, továbbá a relativitás és az egyediség attributúmait mutatja fel).

Ha pedig térben, esetleg földrajzilag gondolkodunk: Michèle Bajolle (2000) un passé contraignant címü könyvében a „külföldet”, a határon túli területet a Deleuze-Guattari-féle nomád térrel azonosítja. Mivel a kommunista Magyarország, a Trilógia egyik fontos színhelye zárt tér, szögesdrótokkal körülvett és aknákkal védett terület, a határon való átlépés egyenlősíthető a nyílt térbe, vagy másképp a Deleuze és Guattari által a Mille plateaux-ban bemutatott nomád térbe (posztmodern térbe) való átmenetellel. A nomád tere szabad, homogén, egyetlen síkból áll, ahol ő bármely irányba mozoghat. Bár a nomádnak megvan a saját területe, és bizonyos utakat követ, ezek az utak nem a mindenki által használt, megszokott utak: ezek csak az övéi. S bár számos referenciapont is létezik a számára, pihenőhelyek, a nomád megint és megint útra kel, hogy átmeneti, függö állapotba, a deterritorializáció állapotába kerüljön (Deleuze és Guattari, 1980, 471. o.). Ehhez még azt is hozzátehetjük, hogy a francia filozófuspáros ezt a fajta teret a modern kapitalizmushoz köti, a kivándorlás célországának gazdasági rendszeréhez, vagyis annak az országénak, amelyet a szereplők elhagyott, kommunistává lett szülőföldjük helyett választanak. A Mille plateaux szerint a posztmodern kapitalizmus éppen a nomadizmus helyével azonosítható. Mireille Buydens azt írja ezen kapcsolatról: 
„Ha perverz módon használjuk a »sima tér« fogalmát, feltehetjük magunknak a kérdést, hogy vajon a simaság nem alkalmas modell-e a financiális posztkapitalizmus elképzelésére, amelyben az értékpapírokkal kapcsolatos áramlások összekoncentrálódnak, nekiiramodnak vagy megcsúsznak, elmozdulnak, s olyan »törvények« szerint »ragozódnak«, amelyeknek több kapcsolatuk van a viharos időjárás titokzatos szükségszerüségeivel, mint az előrejelzésekre képes tudományokkal.”

Illetve magát a könyvet is idézhetjük:

„a beágyazott (vagy inkább beágyazó) nemzetközi kapitalizmus kiegészítő és domináns szintjén, egy új »sima tér« keletkezett, ahol a tőke elérte »abszolút« sebességét. [...] A multik egyfajta deterritorializált sima teret hoznak létre, ahol is a helyfoglalási pontok mint csereüzletek pólusai rendkívüli módon függetlenednek a barázdáltság hagyományos útvonalaitól." (Deleuze és Guattari, 1980, 614. o., ld. Buydens, 2003, 135-136. o.; idézi: Bessis, é.n.)

Megjegyzés: természetesen a nyílt és sima tér legreprezentatívabb motívuma a sivatag, mely képződmény a szerző önéletrajzi könyvében, Az analfabétában - noha más nézőpontból - kötődik az immigráció és emigráció teréhez (A sivatag címü szöveg):

„Hogyan is magyarázhatnám el neki [ti. a busz ellenőrének - F. Gy.] anélkül, hogy megbántanám, és azzal a kevéske szóval, amit tudok, hogy az ő gyönyörű hazája csak sivatag a számunkra, menekültek számára, sivatag, amin át kell kelnünk, hogy megérkezzünk oda, amit úgy hívnak, »beilleszkedés«, »asszimiláció«. Ebben a pillanatban még azt se tudom, hogy néhányan soha nem érkeznek el odáig." (Kristof, 2007, 47-50. о.)

A szövegekben a narráció szintjén is folyamatos határátlépéseknek vagyunk tanúi, tudniillik a keretváltásoknál, és ezzel együtt a narrátor nyelvi értelemben vett személyének megváltozásánál. Ez egy gyakran előforduló jelenség, és az olvasó nem tudja követni, ki beszél (nem tudja névről beazonosítani), továbbá nem tudja ellenőrizni a narrátor szavahihetőségét sem: a keret mozgásai a történetet illetően is mozgásokat (csúszásokat) idéznek elö, és bizonytalanná teszik az identitást.

Ha egyetlen részletre figyelünk, a keretváltozások teljesen átláthatóak is lehetnek: a kezdet kezdetétől tudjuk, hogy egy beékelt történetet olvasunk, valakinek (Peternek, Victornak stb.) a kéziratát, hogy a narrátor egy álmot mesél éppen stb. A Trilógián belül azonban a keretezés szerkezete rizómaként is leírható, azaz egy olyan szövegként, amelynek nagyon sok (nem hierarchizált) bejárata van, vagyis különböző szögekből közelíthetjük meg a narrációját, és amelyben valamilyen rögzített jelentés keresése teljesen fölöslegesnek bizonyul. A két iker sorsát elmesélő A nagy füzetről például csak később tudjuk meg, hogy irodalmi szöveg - minden, ami ott elmeséltetik, fikció (mármint fikció a fikcióban). Ráadásul a Trilógiának nevezett szövegegyüttes minden egyes narratológiai egysége - fejezetek, fejezetrészek, amely a narrátorok (Lucas[Claus] vagy Klaus) „életét meséli el" első szám első vagy harmadik személyben, sőt még az egyik föszereplő kihallgatása nyomán megírt jegyzökönyv is - mind „hazugság”. Ezek egyfelől „fikciók a fikcióban"-nak (vagy 'mise en abyme'-nak) számítanak, másfelöl mint fikciók inkompatibilisek egymással is: egyfolytában módosulnak, s így állandóan megrengetik a többi fikciót. A történetek szavahihetősége egyfolytában megkérdőjeleződik, de nem úgy, mint Kurosawa $A$ vihar kapujában címü filmjében (vagyis ezek az egységek nem különbözö szereplők különféle történetverziói), itt a csúszások, rések, repedések, gyürődések olyan mértéküek és bonyolultságúak, hogy már nem tudjuk, kik a narrátorok, hányan vannak 
(egy van vagy kettő), hogy hívják őket (Claus, Lucas vagy Klaus), miként telt az életük, és hogy a cselekmény megannyi módosítása után vajon várhatunk-e egy újabb csavarra a regényben.

A hazugság eme fajtája alapozza meg a narrációt, és a hazugság mint minden fikció megalapozása erősen tematizálódik is a regényben. (Amúgy nemcsak ebben a könyvben, hanem a Tegnap címüben is, ahol a föhös - Sandor-Tobias - életének két verziója létezik, és amikor a kettő végre összeér, a szereplő abbahagyja az írást és lemond az irodalmi karrierről.) A Trilógia harmadik része, $A$ harmadik hazugság címü valójában három hazugság története. Az események (miszerint az egyik fiú átszökik a határon egy férfival, aki aknára lép, majd a kamaszt letartóztatják a hatóságok) első szám harmadik személyben vannak elmesélve. A fiú azt állítja a rendőröknek, hogy Claus T-nek hívják, 18 éves, és a férfi az apja volt (elbeszélése összecsengeni látszik a történet előbbi verzióival - mármint hogy az ikrek feláldozták apjukat saját szabadságukért). A fejezet azonban így végződik:

„A gyerek aláírja a jegyzőkönyvet, amelyben három hazugság található. A férfi, akivel nekivágott a határnak, nem az apja. A gyerek nem tizennyolc éves, hanem csak tizenöt. Nem Clausnak hívják.” (Kristof, 2013, 399. o.)

És mikor elmondja a rendöröknek, hogy író szeretne lenni, még azt is hozzáteszi:

„Nagyon szeretnék megtanulni írni a maguk nyelvén, de ez elég is nekem.” (Kristof, 2013, 402. o.)

Megtudjuk, hogy a Nagyanyánál - noha róla a továbbiakban kiderül, valójában nem a nagyanyjuk, hanem egy ismeretlen parasztasszony volt - ő már írogatott mindenféle történeteket füzetekbe, és $A$ nagy füzet, a Trilógia első harmada az ő müve: az első regény ekként a „fikció a fikcióban” státusába csúszik át.

„Igazán kíváncsi lennék, mit tartalmaznak ezek a füzetek. Ez valami napló?

Claus azt feleli:

Nem, ezek hazugságok.

Hazugságok?

Igen. Kitalált dolgok. Történetek, melyek nem igazak, de akár azok is lehetnének." (Kristof, 2013, 403. o.)

Michèle Bajolle a skizofréniával magyarázza a narráció ezen trükkjeit a narrátor(ok)ra, a hangra, a legfontosabb motívumokra vonatkoztatva, illetve a test kezelését. Felteszi a kérdést, hogy vajon mit visz színre $A$ nagy füzet: egy dualitást, amely mélyebbre nyúlva egynek bizonyul (vagyis a két szereplő olyan közel áll egymáshoz, hogy ök magukat egynek érzékelik), vagy inkább egy egységet, amely mélyebben véve kettős (azaz egyetlen skizofrén személyt). Szerinte szinte bizonyos, hogy a Trilógia hőse egyetlen személy: A nagy füzetben láthatólag elválaszthatatlannak tünő ,mi”-nek egyetlen hangja van, $\mathrm{s}$ aztán, az egyik iker szökése után - vajon valódi szökés volt ez? - egy szereplö lép közülük színre, s benne megmutatkozván a teljes törés. Még az első részre vonatkoztatva: a gyerekek, miután megverik őket, „elszólják” magukat, ti. hogy „egyen vannak” (ez az elszólás csak a francia verzióban érzékelhető: egyes számban használják a testrészeiket, tehát: „,notre corps”, „notre vue”, „,notre tête”, „,notre bouche” - „, nos corps”, „, nos vues”, „nos têtes”, „nos bouches” helyett). Így lesz teljes a két szereplő és a két név közötti zürzavar (mely ezen kívül narrációs eljárásokban és anagrammatikus játékokban - Lucas/ 
Claus/Klaus - is megjelenik). A regény más szereplői mintegy bizonyítottnak is tekintik ezt az egységet: például a rendőrség grafológiai vizsgálata során állítja, hogy Claus kézirata - melyet szerinte tesvére kezdett el, s ő folytatta később - egy egyszerű fikciót tartalmaz, és egyetlen kéz írta egyazon időben:

„Az írás azonban elejétől a végéig ugyanattól a kéztől származik, és a lapon az öregedés egyetlen jele sem fedezhető fel. A szöveg egésze egyhuzamban íródott, ugyanazon személy által, hat hónapnál nem régebben, tehát csakis Claus T. írhatta itt-tartózkodása alatt."

Michèle Bajolle említett tanulmányában végül arra a következtetésre jut, hogy a Trilógiában a skizofrén elemek együttese és a szöveg posztmodern jellege szükségszerúen behozza az asszociációkat Deleuze és Guattari könyvét illetően, hiszen skizofrén állapot kötődik a nomád léthez is. A kapcsolat világos: a skizofrén (a modern nomád) deterritorializációját a végsőkig viszi, azaz állandó menekülésben van (itt ismét felhívhatjuk a figyelmet a határhelyzet és a határátlépés fontosságára, erősen tematizált jellegére a regényben - ráadásul egyébként egészség és elmebetegség között elég széles határsáv húzódik, amelynek az orvosi neve éppen borderline).

Úgy tűnik azonban, hogy a főszereplők nem csupán fivérükkel azonosulnak (vagy legalábbis akarnak azonosulni), hanem más szereplőkkel is, legfőképp gyerekekkel (illetve rajtuk keresztül a saját fivérükkel). Klaus ezt a testvéri egyesülést leginkább saját nevelt fiával, Mathias-szal szeretné kiteljesíteni, de olykor más gyermekeket a hajdani saját magának látja. A pályaudvaron azt mondja a hordárfiúnak:

„- Látom, messzire sem tudnád vinni. Előtted én csináltam ezt a munkát.

A gyerek leteszi a böröndöt:

- Ó, igen? Mikor?

- Amikor annyi idős voltam, mint te. Sok ideje már annak."

A nőnél, aki felneveli, Klaus a születendő gyermek kiságyában alszik annak világra jöveteléig (azonosul az asszony magzatával), miközben olyan érzése is támad, hogy a megszületendő gyermek Lucas lesz (a három gyermek, Lucas/Klaus/Sarah így olvadnak egymásba):

„Minden alkalommal, amikor Antonia az ölében ringatott, éreztem a baba mozgásait, és azt hittem, Lucas az. Tévedtem. Antonia hasából egy kislány jött ki." (Kristof, 2013, 432. o.)

(Képzelt fúziók ezek, identifikációs fúziók, testi fúziók, vagyis minden határnak a lebontása, minden olyan határnak, amelyet a szereplőnek, a személyiségnek, az identitásnak, a testnek, a szexuális bináris rendszernek szokás tulajdonítani: az eredmény vajon értelmezhető egyfajta CsO-nak, szervnélküli testnek? Némileg kockázatos hipotézis, de talán nem minden megalapozás nélkül való.)

Egy másik fontos aspektus a nyelvi: Agota Kristof (2007, 30. o.) Az analfabétájában s különböző interjúiban azt állítja, valójában sohasem tanult meg tökéletesen franciául (sem írni, sem beszélni), ráadásul számára a francia egy „ellenséges” nyelvvé vált, amely folytonosan gyilkolja az anyanyelvét: gyökértelensége tehát alapvetően nyelvi jellegü.

Ebböl a szempontból azt a fajta kisebbségi irodalmat müveli, amelyet Deleuze Kafkáról írott könyvében határoz meg, még ha Agota Kristof státusza amúgy teljesen más, mint a Prágában élő németajkú zsidó íróé volt a Monarchia idején. A két szerzőt összetartja 
az írás - külső és belső - kényszere. Kafkát illetően Deleuze (1975, 42-43. o.) ezt egy paradoxonban fogalmazza meg: ,a nem írás lehetetlensége, a németül írás lehetetlensége, a másképpen írás lehetetlensége". Agota Kristof (2007, 57-61. o.) viszont ezt írja:

„Ezt a nyelvet nem én választottam. Számomra a sors, a véletlen, a körülmények által ez a nyelv adatott. Franciául írni: erre vagyok kényszerítve. Mindez kihívás. Kihívás egy analfabéta számára."

Márpedig az analfabéta itt a kisebbségi irodalom praxisát jelenti:

„Hány ember él ma olyan nyelvben, amely nem a sajátja? Hányan vannak, akik már, vagy még nem ismerik saját nyelvüket, és rosszul ismerik azt a többségi nyelvet, amelyet használni kényszerülnek? A bevándorlók, s föként gyermekeik problémájáról van szó. A kisebbségek problémájáról. A kisebbségi irodalom problémájáról, ami azonban mindannyiunkat érint: hogyan szakítsunk ki nyelvünkből egy olyan kisebbségi irodalmat, amely képes aláásni a nyelvet, és józan forradalmi vonal mentén elfojtani azt? Hogyan lesz valaki saját nyelvének nomádja, bevándorlója, cigánya? Kafka válasza: gyermeket bölcsőjéből kilopva, kifeszített kötélen táncolva." (Deleuze, 1975, 40. o.)

A kisebbségi irodalom a domináns nyelvet idegenségben tartja a saját maga számára is, a szélsőségeiig, a végső határáig viszi el, azért, hogy kivonja hivatalos, a hatalom szolgálatában álló használata irányítása alól, és intenzíven, nem utalásos módon alkalmazza (Duplay, 2003, 216. o.). A kisebbségi irodalom egyik jellemzője (a politika állandó jelenléte és a megnyilatkozás kollektív jellege mellett) a „nyelv deterritorializációja” (Deleuze, 1975, 33. o.). A regény nyelve két látszólag összeegyeztethetetlen vonással bír: egyrészt nem-referenciális, pl. A nagy füzetben nincsenek tulajdonnevek: a gyerekek a Nagyvárosból érkeznek, az ikreket többnyire a „mi”, a többes szám első személy jelöli, s vagy a családi, vagy a társadalmi státusz helyettesíti a nevet (Anyánk, Nagyanya, a plébános, a tiszt), vagy csúfnevet használnak valaki megnevezésére (Nyúlszáj). Más megoldás:

„Nagyanya azt mondja ránk:

- Szukafattyak.

Az emberek azt mondják ránk:

- Boszorkányfajzat! Kurvafattyak!

- Mások meg azt:

- Hülyék! Csibészek! Taknyosok! Szamarak! Mocskosok! Disznók! Rohadékok!

Dögök! Szarháziak! Akasztófavirágok! Gyilkospalánták!"

Kész bestiárium, amely teljes ellentétben áll az anya becéző szavaival:

„Kedveseim. Drágáim. Mindenségeim. Imádott kicsikéim.”(Kristof, 2013, 23-24.o.)

Első benyomásunk az lehet, hogy a másik vonás a fent bemutatottal tökéletes oppozícióban van. A kritika gyakran említi, hogy Agota Kristof szövegei nyelvileg rendkívül egyszerüek, minimalista írásmód jellemzi - egyfajta stílushatásként - az egész életmüvet. Ez a minimalizmus azonban (egyszerü szintakszis, korlátozott szókincs) a figyelmetlen befogadó számára akár „kvázi-referenciálisnak” is tűnhet, amit az is megerősít, hogy a két naplóíró gyerek ,ars poeticája” a teljes, minden érzelmet kiiktató objektivitásra épül, ámde ez az objektivitás és referencialitás illuzórikusnak bizonyul a szöveget teljesen feldúló bizonytalanságok, elcsúszások, hazugságok közepette. 
„...igaznak kell lennie. Azt kell leírnunk, ami van, amit látunk, amit hallunk, amit csinálunk. Tilos például azt írni, hogy »Nagyanya olyan, mint egy Boszorka«, de azt szabad írni, hogy »az emberek úgy nevezik Nagyanyát, hogy a Boszorka«." „Azt írjuk, hogy »sok diót eszünk«, és nem azt, hogy »szeretjük a diót«, mivel a »szeret« bizonytalan szó, nem pontos és nem tárgyilagos”. (Kristof, 2013, 29. o.)

A kisebbségi irodalomnak ez a fontos sajátossága - amely „szándékosan megöl minden metaforát, minden szimbolizmust, csakúgy, mint minden kijelölést”, s ahol nincs sem szószerinti, sem átvitt jelentés, csak a szó által biztosított skálában hangulati állapotok - megjelenik Agota Kristofnál is, bár másképpen, mint a Deleuze számára a kisebbségi irodalom reprezentáns figurájának számító Kafkánál.

Ennek a minimalizmusnak mindazonáltal más oka is lehet: mint ahogy Cécile Kovácsházy (2003) is írja, Agota Kristof ugyan teljesen korrektül, nyelvtani hibák nélkül ír franciául, az általa választott nyelv elválik az irodalmi nyelvi regisztertől rövid, tömör volta miatt, ami Agota Kristof stílusát keménnyé, durvává teszi. Szerinte ez a stílussajátosság annak köszönhetö, hogy a szerző a magyar nyelvet másolja, átteszi franciába - márpedig ő úgy látja, az állítmányból a kopulát olykor kihagyó magyar nyelv tömörebb a franciánál. (Én ezt a véleményt kicsit árnyalnám: még ha ez az állítás igaz is lenne - de nem biztos, hogy mindig megállja a helyét -, Agota Kristof nyelvezete akkor is metszőbb és keményebb annál, semmint hogy erre az egyetlen okra vezessük vissza stílusjellemzőit.)

Agota Kristof egy olyan hibrid nyelvet alkot meg, amely soha nem létezett a két régebbi kereszteződésénél. Ez olyasféle hibrid vagy kiborg nyelv, amelyről például Donna Haraway beszél kiáltványában a gyarmati területekről származó nőírókkal - pl. Cherríe Moragával - kapcsolatban. Bár Agota Kristof nem színesbőrü nő és nem leszbikus, társadalmi helyzete (túlképzett munkás), bevándorló státusza, írói ambíciói melletti kitartása, hibrid nyelvhasználata és homályos körvonalú narrációs technikája, illetve (az elöbbiekkel együtt) saját identitása Haraway (2002) kiborgjaihoz lesz hasonlatossá (saját nemét ugyan az ellentétébe fordítja, de meg is zavarja, vagy homályossá is teszi egyszersmind):

„A kiborg a gender utáni kor teremtménye; nincs semmi köze a biszexualitáshoz, a preödipális szimbiózishoz, az el nem idegenedett munkához, vagy az organikus teljesség egyéb csábításaihoz, amelyek egy magasabb egység érdekében végleg kisajátítják a részek minden hatalmát. A kiborgnak bizonyos tekintetben nincs a nyugati értelemben vett eredettörténete, ami végső irónia, hiszen kiborg az a télosz is, amelyhez a Nyugat elvont individuációjában megjelenő megjelenő uralmi viszonyainak eszkalálódása vezet; a végső én, amely végre felszabadult minden függés alól; az ember az ürben. [...] A kiborg a részlegesség, az irónia, a meghittség és a perverzió elszánt híve. Oppozicionális, utópikus, és nélkülöz mindennemủ ártatlanságot."

Köztes állapotban lenni, sehová sem tartozni, határsávban lenni, miközben éppen áthaladunk rajta, ez a bevándorló élethelyzete - de vajon ez nem remek lehetőség is arra, hogy megtaláljuk szubverzív kifejezésmódunkat, mint ahogy azt a nomád, a hibrid, a kiborg teszi? 


\section{Irodalomjegyzék}

Bajolle, Michèle (2000): un passé contraignant. double bind et transculturation. Rodopi, Amsterdam - Atlanta, GA.

Buydens, M. (2003): Espace lisse / espace strié. In: Sasso, R. és Villani, A. (szerk.): Le vocabulaire de Gilles deleuze. Les Cahiers de Noesis, 3. sz. Printemps, 135-136., cité par Raphaël Bessis, Le vocabulaire de deleuze, 2015. 06. 17-i megtekintés, http://www.caute.lautre.net/rubrique.php3?id rubrique=133; http ://vadeker.net/humanite/ philosophie/vocabulaire_deleuze.pdf

Deleuze, G. (1975): Kafka. Minuit, Paris.

Deleuze, G. és Guattari, F. (1980): Mille plateaux, 2. capitalisme et schizophrénie. Minuit, Paris.

Duplay, M. (2003): Littérature mineure. In: Sasso, R. és Villani, A. (szerk..): Le vocabulaire de Gilles deleuze, Les Cahiers de Noesis, 3. sz. Printemps, Cité par: Vocabulaire de deleuze (réalisé par Raphaël Bessis); http://www.cite.uqam.ca/magnan/wiki/ pmwiki.php/AER/VocabuDeleuze; http://vadeker.net/ humanite/philosophie/vocabulaire_deleuze.pdf (Letöltve: 2015. 06. 17.)

Haraway, D. (2002): Kiborg-kiáltvány: tudomány, technológia és szocialista feminizmus az 1980-as években. In: Bókay Antal, Vilcsek Béla, Szamosi Gertrud és Sári László (szerk.): A posztmodern irodalomtudomány kialakulása. Osiris, Budapest. 503-519.

Kovácsházy, C. (2003): La duplicité de la trilogie d'Agota Kristof. In: Szende,Th. és Máté, Gy. (szerk.): Frontières et passages: actes du colloque francohongrois sur la traduction. Lang, Bern. 129-140.

Kristof, A. (2007): Az analfabéta. Önéletrajzi írások. Palatinus, Budapest.

Kristof, A. (2007): Mindegy. Novellák és színmüvek. Cartaphilus, Budapest.

Kristof, A. (2013): Trilógia. Cartaphilus, Budapest.

Lévi-Strauss, C. (1949): Les structures élémentaires de la parenté. PUF, Paris. 